
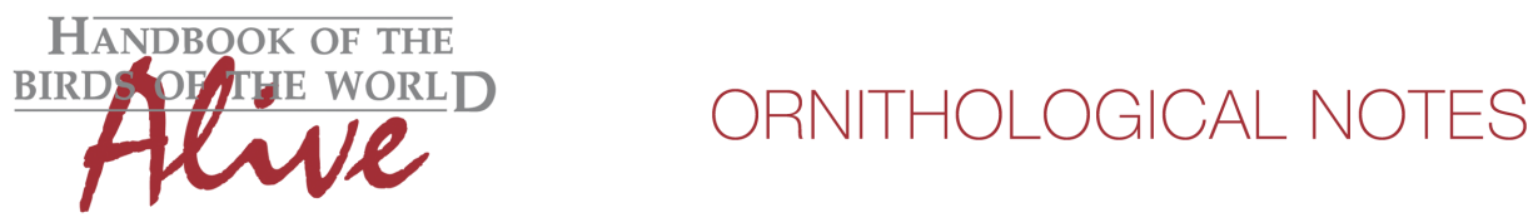

\title{
Notes on the vocalizations of Blue-throated Blue-flycatcher (Cyornis rubeculoides)
}

Peter Boesman

In the following we briefly analyze and compare voice of the different races of Blue-throated Blueflycatcher (Cyornis rubeculoides). We also try to quantify the extent of any vocal differences using the criteria proposed by Tobias et al. (2010), as a support for taxonomic review. We have made use of sound recordings available on-line from Xeno Canto (XC).

Race glaucocomans has long been considered possibly a distinct species (HBW Alive: Clement 2016), and voice is said to be generally richer, with varied warbling notes, and more sustained. Voice of glaucicomans was also discussed more recently (Zhang et al. 2016) but again differences are described only qualitatively as having much longer strophes, with repetitions of complex phrases, and a deeper richer voice.

A comparison of song illustrated with sonograms:
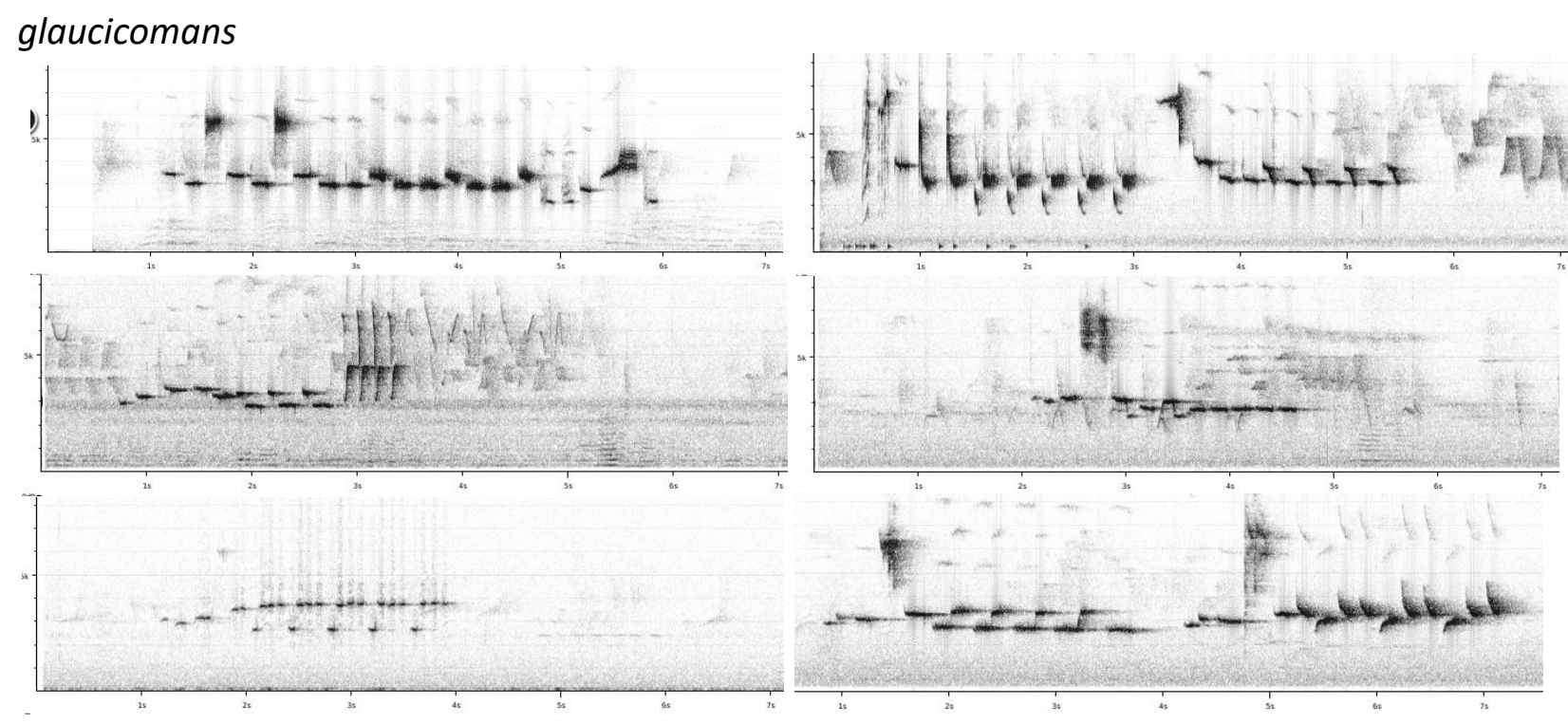

While not all song strophes are typical, repetition of a theme is almost always present (themes are either a single note, or more often 2-3 notes and occasionally more).

Most song strophes are longer than 2.5s. Most notes have a maximum frequency below $4 \mathrm{kHz}$.

Strophes typically have some 10-20 notes. 

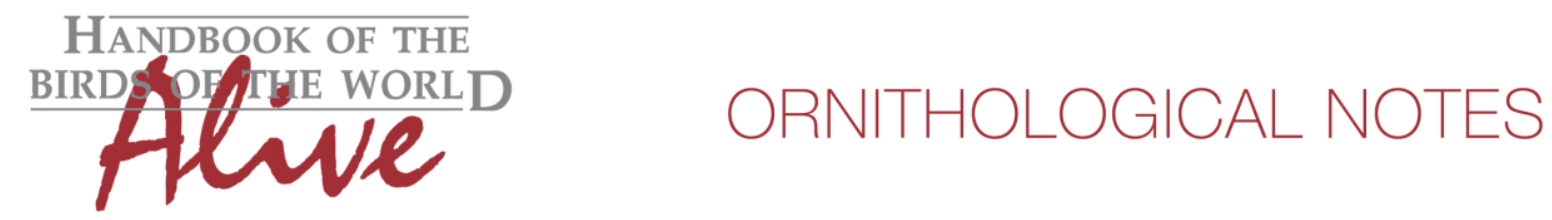

Some examples of other races:
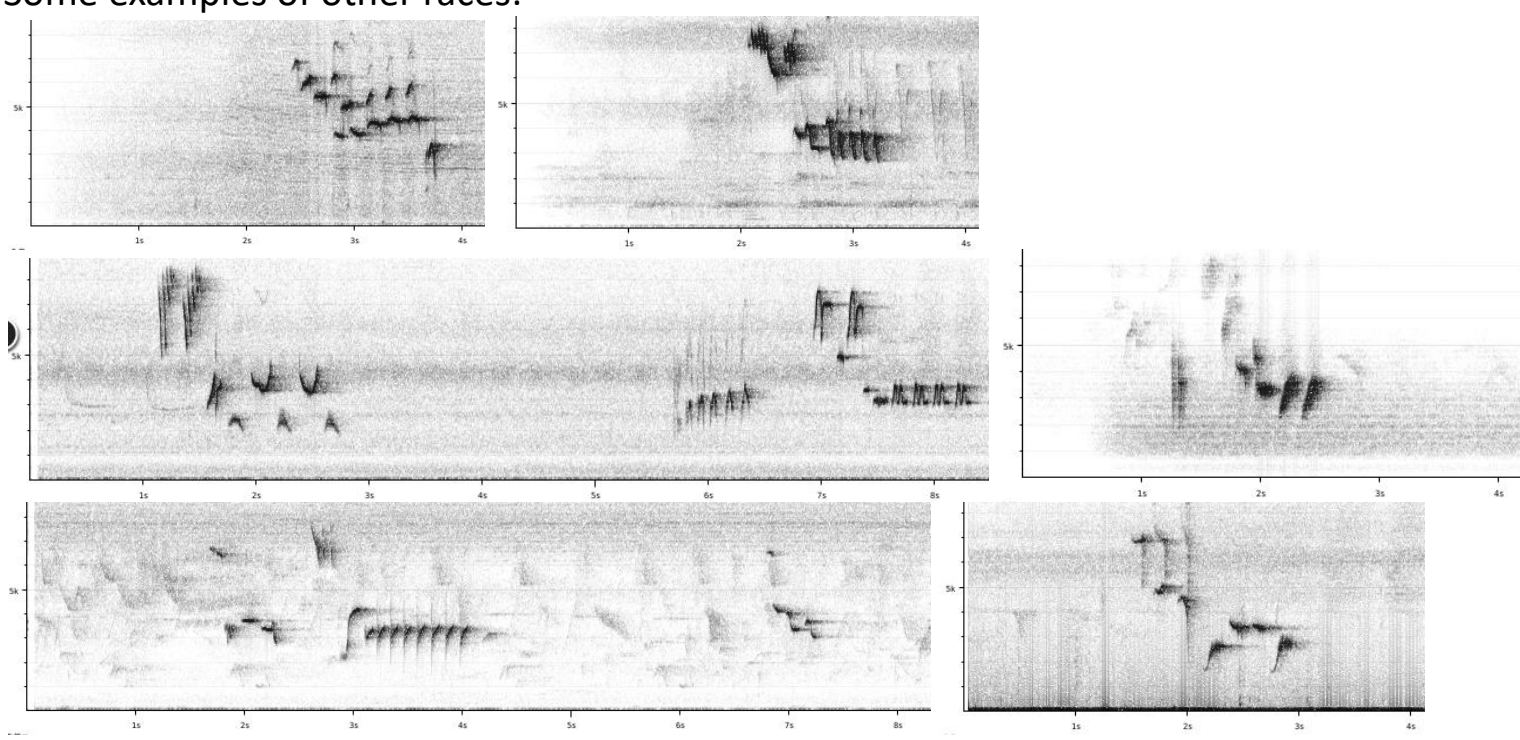

Repetitions of single notes occur, repeated themes of two or more notes however are not really identical. Song strophe typically is shorter than 2s. Strophes typically have some 10-15 notes. Note cover a fairly wide frequency range.

There are thus some clear vocal differences, which can be quantified as follows: glaucicomans has longer song strophes (2-3) which have more notes (1-2) and much more repetitions of themes (12). Furthermore average frequency of notes is (only) slightly lower-pitched (allow 1). When applying Tobias criteria, this would lead to a total vocal score of about 4.

This note was finalized on 6th May 2016, using sound recordings available on-line at that moment. We would like to thank in particular the sound recordists who placed their recordings for this species on XC: Per Alström, Nick Athanas, Mike Catsis, Thijs Fijen, Greg Irving, Vijay Ismavel, Vir Joshi, Frank Lambert, Hari Mavelikara, Mike Nelson, Sander Pieterse, Craig Robson, Benj Smelt, Ankit Vikrant and Bram Vogels.

\section{References}

Clement, P. (2016). Blue-throated Blue-flycatcher (Cyornis rubeculoides). In: del Hoyo, J., Elliott, A., Sargatal, J., Christie, D.A. \& de Juana, E. (eds.). Handbook of the Birds of the World Alive. Lynx Edicions, Barcelona. (retrieved from http://www.hbw.com/node/59094 on 6 May 2016).

Tobias, J.A., Seddon, N., Spottiswoode, C.N., Pilgrim, J.D., Fishpool, L.D.C. \& Collar, N.J. (2010). Quantitative criteria for species delimitation. Ibis 152(4): 724-746.

Zhang, Z., Wang, X., Huang, Y., Olsson, U., Martinez, J., Alström, P. \& Lei, F. (2016). Unexpected divergence and lack of divergence revealed in continental Asian Cyornis flycatchers (Aves:

Muscicapidae). Mol. Phylogenet. Evol. 94: 232-241. 


\section{Recommended citation}

Boesman, P. (2016). Notes on the vocalizations of Blue-throated Blue-flycatcher (Cyornis rubeculoides). HBW Alive Ornithological Note 317. In: Handbook of the Birds of the World Alive. Lynx Edicions, Barcelona. (retrieved from http://www.hbw.com/node/1251852 on 18 October 2016). 